\title{
Z3 THE IMPACT OF GST (GOODS AND SERVICE TAX) IN INDIA-A SPECIAL REFERENCE TO RESTAURANTS BUSINESS IN INDIA
}

\author{
Dr. B. Mahammad Rafee ${ }^{1}$, Asst. Prof. Arunjyothi ${ }^{2}$ \\ E-Mail Id: basharafee@gmail.com

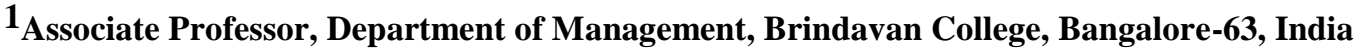 \\ $\mathbf{2}$ Assistant Professor, Department of Management, Brindavan College, Bangalore-63, India
}

\begin{abstract}
The objective of the study is to highlight the impact of GST on restaurant business in India. The study adopted exploratory research technique based on past literature from respective journals, reports, news papers and magazine covering wide collections of academic literature on impact of new taxation reform on restaurant business. On the other hand the paper gives insights in the pre and post taxation policy of the government on food industry. The study concludes on the basis of the literature that GST's impact will be having both positive and negative implications on food sector i.e. higher the tariff on restaurants (where room tariff more than 7500) have 18\% tax which is regressive in nature which reduces the frequency of people visiting to restaurants and the lower tariff hotels with 5\% GST have benefited. Where as in comparison with other neighboring countries like China, Malaysia and Singapore the GST rate is higher in India.
\end{abstract}

Keywords: Goods and Service Tax (GST), Value added Tax (VAT), Restaurant Business, Input tax Credit (ITC).

\section{INTRODUCTION}

India's restaurant industry is said to be worth of almost ₹75,000/-crores and is growing at a annual rate of 7\%. The industry is fragmented with 1.5 million eating outlets majority are under unorganized sector $(86 \%)$ the remaining $14 \%$ are only organized. Whereas the organized segment is expected to grow rapidly to the tune of ₹22,000 crores in urban India due to the raising disposable income, nuclear family structure, increasing working population (more women joining the workforce), rapid urbanization and consumerism etc. This is also one of the major sector where more revenue can be generated by the Government by taxation. On the other hand the e-commerce food platforms are tapping the opportunity with their business strategy and connecting customers with restaurants namely Swiggy, Zomato and Uber eats are increasing their business prospects.

Restaurants are now levied a 5\% GST, but they cannot claim the input credit against the tax they paid on raw materials and other expenses like rent etc. the national restaurant association in India which represents 5 lakh restaurants objected that the denial of the input tax credit had caused a severe impact on the sector and led to the closure of 20,000 outlets in the country in 2019. So, there was a decline in the growth rate up to $2 \%$ in the year 2019 compare to previous fiscal. The study aims to brief the impact of GST on Restaurant business in India.

\subsection{GST}

GST is a tax on consumption which is levied on the basis of Principle of destination at the final consumption point. It avoids the cascading effect or a tax on tax which increases the tax burden on the end consumer. It is something like a merchant pays to procure goods or services can be set off later against the tax applicable on supply of goods and services. In other words, GST replaces multiplicity of taxes imposed by central and state governments, which subsumes all indirect taxes like Central Excise duty, commercial tax, Octroi tax/charges, VAT (Value added tax) and service tax. Therefore, manufacturers, wholesalers and retail merchants can avail tax credit mechanism under GST régime. It is conceptualized as 'One Nation and One tax' and expected to eliminate the existing cascading tax structure, ease compliances and create uniform tax rates and structure and may help in reducing additional tax burdens on consumers. As a part of Major taxation reform post-independence and to increase the Tax to GDP ratio the Govt. of India had rolled out GST from $1^{\text {st }}$ July, 2017, Where in his Budget speech the then Finance Minister said India is a non-compliant tax society as $36 \%$ of employees only fill tax returns in organized sector and $33 \%$ in informal sector and $43 \%$ of the registered companies. Indian Tax to GDP ratio is at $16.6 \%$ which is well below the emerging market economies and OECD average about $21 \%$ and $34 \%$ respectively.

Under this system of taxation, the end consumer pays the final tax but an efficient input tax credit system ensures that there is no cascading of taxes- a tax on tax paid on inputs that enter the manufacture of Products. In order to avoid the payment of multiple taxes like central sales tax, service tax and excise duty at the Central level and VAT at the State

DOI Number: https://doi.org/10.30780/IJTRS.V05.I02.003

pg. 19

Www.ijtrs.com

www.ijtrs.org 


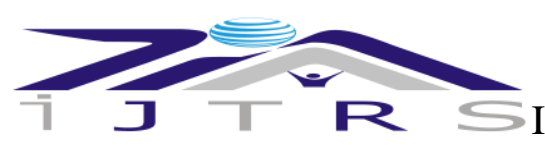

level, GST would unify these taxes and make a consistent market throughout the country. The integration of varied taxes into a GST system will cause an efficient cross-utilization of credits. The data on GST revels that the tax collection has dropped below ₹1 lakh crore mark to ₹ 91,916 crores for September 2019 which is declined to $2.67 \%$ in comparison to the revenue during September 2018(Paisa Bazar.com).

The National Restaurant Association of India's in the year 2013 in its foodservice report discloses that the Indian food service industry is ₹2,47,680 crores and is predicted to increase by 2018 to ₹4,08,040 crores which is at the rate of $11 \%$. This growth is due to the growth of the good Indian bourgeoisie, rapid urbanization, growing awareness of western life style, and more women joining the workforce and better disposable income were some of the factors that have contributed to the growth of the restaurant industry in India.

\subsection{Presumptions Prior to Implementation of GST}

Shefali Dani (2016) investigated the effect of GST execution in India and repeats that GST would be fruitful just if the nation has a solid IT arrange and presume that it's a weak endeavor to excuse circuitous duty structure. The administration of India should examine the GST system discovered by different nations and furthermore their aftermaths before actualizing it. At an identical time, the govt should put forth an attempt to protect the huge poor populace of India against the reasonable swelling because of execution of GST. Presumably, GST will improve the common assessment framework and can assist with disposing of wasteful aspects made by the predominant flow heterogeneous tax collection framework as long as there's an a reasonable accord over issues with edge limit, income rate, and consideration of oil based goods, power, alcohol and land.

Rishi Gupta (2017) contemplated the effect of GST in India and reasons that the GST system will give alleviation to makers and buyers by giving wide and far reaching inclusion of info charge credit set-off, administration charge set off and subsuming the few assessments. Productive plan of GST will cause asset and income gain for both Center and States significantly through enlarging of expense base and improvement in charge consistence. It are frequently additionally inferred that GST positively affect different divisions and industry.

\subsection{Benefits of GST (Goods and Service Tax)}
$>$ It would introduce two-tiered One-Country-One-Tax regime.
$>$ It would subsume all indirect taxes at the center and therefore the state level.
$>$ It wouldn't only widen the tax regime by covering goods and services but also make it transparent.
$>$ It would free the manufacturing sector from cascading effect of taxes, thus by improve the cost- competitiveness of goods and services.
$>$ It would bring down the prices of goods and services and thus by, increase consumption.
$>$ It would create business-friendly environment, thus by increase tax-GDP ratio.
$>$ It would enhance the convenience of doing business in India.

\subsection{Drawbacks of GST}

Wall Street firm Goldman Sachs, in an exceedingly note 'India: Queries and Answers on GST — Growth Impact might be Muted', has place out appraisals that the Modi Government's model for the Goods and Services Tax (GST) won't raise development, will push up purchaser costs swelling and may not prompt upgraded charge pay assortments. There are by all accounts certain provisos inside the anticipated GST charge system which can be prejudicious in conveying the predefined results.

They are: India has embraced double GST as opposed to national GST. It's made the entire structure of GST genuinely troublesome in India. The Center can need to facilitate with twenty-nine states and seven association domains to actualize such duty system. Such system is most likely going to shape financial just as political issues. The states are conceivable to lose the state in deciding rates once GST is authorized. The sharing of incomes between the states and furthermore the Centre stay a matter of conflict with no accord showed up identifying with income unbiased rate. One among the principle downsides of the GST system might be the immediate spike inside the administration charge rate from $14 \%$ to $20-22 \%$.

The oil items are a noteworthy supporter of growth in India because of $80 \%$ of energy wants are met through imports. inflammation in India relies upon how the administration proposes to take in oil based commodities under GST in future. Power is vital for the extension and improvement of India. On the off chance that power is encased beneath standard or extravagance stock in future, at that point it'd gravely affect the advancement of India. It's said that GST would affect adversely on the land promote. It would mean $8 \%$ to the expense of new homes and scale back interest by about $12 \%$. The study comprise on four components, first part includes the introduction to the GST its benefits and disadvantages and objectives of the study. Second part of the study consists of a brief note on Food and Restaurant business in India and literature review of the study. Third part includes the pre and post GST tariff in hotel industry. The fourth part the study offers conclusion and policy suggestions.

DOI Number: https://doi.org/10.30780/IJTRS.V05.I02.003

pg. 20

WWw.ijtrs.com

wWw.ijtrs.org

Paper Id: IJTRS-V4-I12-011

@ 2017, IJTRS All Right Reserved

Volume V Issue II, February 2020 


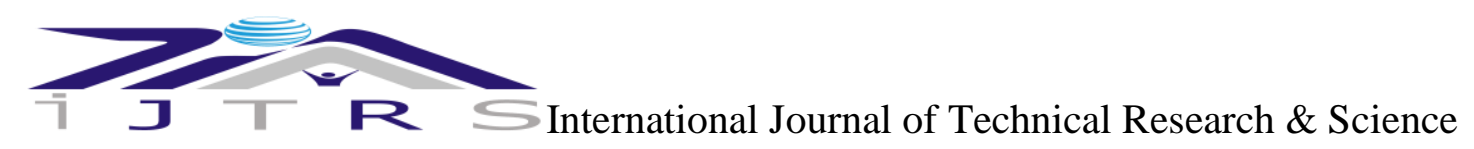

\section{METHODOLOGY OF THE STUDY}

The paper uses an exploratory research model based on past literature from respective Journals, reports, newspapers and magazines covering wide collection of academic literature on Goods and Service Tax.

\subsection{The Objectives of the Paper are}

$>$ To study about Goods and Service Tax and its impact on restaurant business in India

$>$ To offer Policy Suggestions

\subsection{Limitation:}

The study only focuses on the impact of GST on restaurants business India will analyse the phenomenon using past literature with current revised tariff and its pros and cons on the food industry. Macro-economic data on GST contribution by restaurants in proportionate to the share of total GST is not available to apply statistical tools to derive the exact impact.

\subsection{Food and Restaurant Industry}

Since food constitutes an oversized portion of the consumer expense of lower income households, any tax on food would be regressive in nature i.e. it could impact the consumption pattern of the society. Therefore, extending GST to food processing sector will cause difficulty visible of the very fact that production and distribution of food is essentially unorganized in India. On global front, most of the countries tax food at a lower rate keeping in sight the considerations of fairness and equity. Even in few countries like Canada, UK and Australia where food constitute a comparatively small portion of the consumer basket, food is taxed at zero rates. While in some countries, food is taxed at a typical rate which is as low as 3\% in Singapore and Japan at the inception of the GST. Even in international jurisdictions, no distinction is drawn on the degree of processing of food. Hence, the advantage of lower or zero tax rates should even be extended to any or all food items in India regardless to degree of processing. Whereas India thinks about GST on food services is 5\%,12\% or $18 \%$ depending on the verity of things including but not limited to form of establishment and place of restaurant or food service provider. GST on food services replaced the former VAT and service tax regime. However, the service fee which is implemented by restaurants is separate from GST. GST on food is applicable to food items purchased by the individual which is currently at $18 \%$

\section{LITERATURE REVIEW}

Diksha panwar and Sidheswar Patra (2017) dissected the effect of GST on Restauraunts and nourishment administration business in India , the target of the examination was to discover the experiences in execution and to feature the unfavorable impacts of cafés and nourishment industry. The investigation presumes that incessant change in charge rates and backward tax collection strategy disheartens the new contestants in the café business.

Dr.Kala Ganeshan and Deepa (2017) conveyed a contextual analysis on GST in the administration area with extraordinary reference to Hotel industry. The goal of the investigation was to examine an outcomes of GST on Chidambaramvials extravagance resort. The investigation finishes up at a positive note that it's a straightforward and uniform assessment the nation over which could decrease tax avoidance and make sends out increasingly serious, could carry more income to the exchequer.

Shana and Rohit bhat (2018) analyzed issues of GST on lodging industry in Mysore area, the investigation objective was to inspect the discernments towards GST among buyers based on populace extent and the examination dependent on test study. The examination finds and reasons that the age bunch till $30 \mathrm{yrs}$ in the area were not having clear comprehension on the framework than the above age gatherings. Not many of the clients have the issue in installment of extravagance charge. The execution of GST had diminished the installment of different charges at each phase of business movement and perceived as one assessment.

Aswathy Krishna and et.al (2018) dissected the impacts of GST on inn industry. The examination portrays the upsides and downsides of the GST in the inn business and it infers that organizations which centers around nourishment and refreshments could be the greatest recipients with in the neighborliness sector(budget inns profited), the inns with the levy scope of $18-28 \%$ hit gravely.

Bharati Sharma and et.al (2018) read important tax assessment framework for café industry contrasting VAT and GST and investigating the effect on buyer and eatery proprietors. The examination presumes that GST is important framework for both eatery proprietors and customers, improving the fundamental portion of buyer by decreasing the taxation rate. It will straightforwardly affect on the productivity of entrepreneur as decreased expense draw in more clients and will expand the market development of café industry additionally the GDP of Indian Economy.

Ann Abraham and Dr.Tomy Mathew (2019) considered the effect of GST on Hotels in Kerala, the examination objective was to take a gander at the assessments of hoteliers and dissect the issues looked by the hoteliers and to search out the ascent in consistence cost of GST. The investigation dependent on testing infers that presentation of

DOI Number: https://doi.org/10.30780/IJTRS.V05.I02.003

pg. 21

$$
\begin{aligned}
& \text { www.ijtrs.com } \\
& \text { www.ijtrs.org }
\end{aligned}
$$




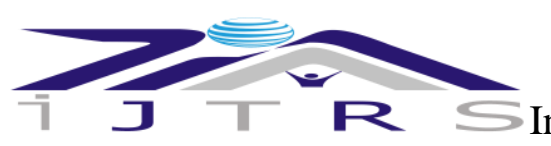

GST rates in inns met with obstruction from the hoteliers. In any case, after the update in charge rates larger part of hoteliers communicated confidence inside the framework. Though greater part of them have brought about extra expense on the move towards new arrangement of tax assessment it has been effective.

Faizanbhai A.Saeeda (2019) this paper gives a rundown of effect of GST on different parts of eateries and lodging organizations in Anand and Nadiad area. The examination received example study utilizing factors like deals, benefit and purchasing by the eateries and so forth. The examination presumes that GST influences positive on offers of inns and cafés and on the obtaining by lodgings and eateries it influences positive to unbiased and just if there should be an occurrence of eatery the benefits stay consistent.

\subsection{Pre and Post GST Tariff on Restaurants}

Pre-GST taxation was found to be with Service Tax, Service fee, and VAT being added over and above the food value.

The components of the bill were:

$>$ VAT: This is often the tax charged on the food portion of your bill was wont to be $14.5 \%$

$>$ Service tax: This is often the tax charged on the services provided by the restaurant. Service tax is not an income and merely a tax collected from you and submitted to the govt. To avoid unnecessary complications government had already divided the service portion and food portion and charge taxes accordingly. The Service tax used to be $14 \%$.

$>$ Service Charge: This is a charge applied by the restaurants and not by the government. The service fee wont to be $10 \%$.

$>$ Krishi Kalyan Cess of $0.5 \%$ and Swach Bharat Cess of $0.5 \%$ wont to be levied additionally.

Table-3.1 GST Rates on Eating Out (with effect from 01.10.2019)

\begin{tabular}{|l|l|l|}
\hline S. No & Type of Restaurants & GST Rate \\
\hline 1 & Railways/IRCTC & $5 \%$ without ITC \\
\hline 2 & Standalone restaurants & $5 \%$ without ITC \\
\hline 3 & Standalone outdoor catering services & $5 \%$ without ITC \\
\hline 5 & $\begin{array}{l}\text { Restaurants within hotels } \\
\text { (Where room tariff is less than ₹ 7,500) }\end{array}$ & $5 \%$ without ITC \\
\hline 6 & $\begin{array}{l}\text { Normal/composite outdoor catering within hotels (Where } \\
\text { room tariff is less than ₹ 7,500) }\end{array}$ & $5 \%$ without ITC \\
\hline 7 & $\begin{array}{l}\text { Restaurants within hotels* } \\
\text { (Where room tariff is more than or equal to ₹ 7,500) }\end{array}$ & $18 \%$ with ITC \\
\hline
\end{tabular}

$>$ This covers individuals supplying catering or other services in hotels (having room tariff of ₹7,500 or more) and not any hotel accommodation services.

$>$ In the GST regime, the Service Tax and VAT amount will be subsumed into one single rate, but you may still find service charge doing rounds on your food bill.

$>$ Below we have provided a high-level comparison of how your food bill will look pre and post-GST.

\section{FINDINGS AND SUGGESTIONS}

Introduction of GST rates in hotels met with resistance from the hoteliers. However, after the revision in tax rates majority of hoteliers expressed faith in the system. It is transparent and uniform tax across the country which could reduce tax evasion and could bring more revenue to the exchequer.

Even though majority of them have incurred additional cost in transition towards new system of taxation it's been successful. The frequent change in tax rates and regressive taxation policy discourages the new entrants within the restaurant business.

Companies which focuses on food and beverages are found to be the most important beneficiaries with within the hospitality sector (budget hotels benefited), the hotels with the tariff range of 18-28\% hit badly. On the opposite hand

DOI Number: https://doi.org/10.30780/IJTRS.V05.I02.003

pg. 22

WWw.ijtrs.com

www.ijtrs.org 


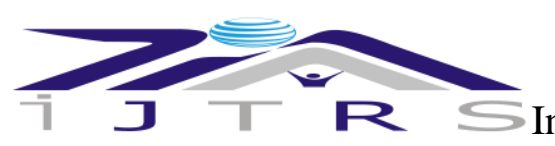

International Journal of Technical Research \& Science

the new GST rate structure will help the tiny restaurants would have a positive impact on cloud kitchen and food delivery business as they might charge significantly less than AC food establishments and high-end restaurants.

If the government approves the choices proposed by the National Restaurant Association " "those who don't want to claim the input tax credit be levied 5\% GST and people who able to pay $12 \%$ be allowed to claim the refund", would benefit majority of the restaurants and propel the expansion of emerging food industry within the country.

\section{REFERENCES}

[1] Saeeda, F. A. (2019). GST: Impact of GST on Various Aspects of Restaurants and Hotel Business in Anand and Nadiad District. Journal of Information and Computational Science, 352-358.

[2] dani, s. (2016). A Research Paper on an Impact of Goods and Service Tax (GST) on Indian. Business and Economics.

[3] Gupta, D. R. (2017). Goods and Service Tax- A Positive Reform In Indian Taxation. International Journal of Management Research \& Review, 674-680.

[4] Patra, D. P. (2017). Impact of Goods and Services Tax on Restaurants and food service Businesses in India. International Journal of Applied Business and Economic Research, 203-213.

[5] Bhat, S. a. (2018). A study on the problems of Goods and Services Tax on Hotel Industry in Mysore District. Journal of Business and Management-IOSR, 49-52.

[6] Bhushan, R. (2019, june 10). m.economictimes.com. Retrieved from www.economictimes.com

[7] Deepa, D. G. (2017). A Case Study on GST In Service Sector Particularly In Reference to Hotel Industry. Journal of Management and Science, 33-41.

A. K. (2018). A study on GST and its effects on hotel industry. Journal of Business and Management-IOSR, 4-5.

[8] Mathew, A. A. (2019). A Study on the Impact of Goods and Services Tax Reform on Hotels in Kerala. International Journal of Management Studies, 54-61.

[9] Patra, D. P. (2017). Impact of Goods and Services Tax on the Restaurants and Food service Businesses in India. Internaitonal Journal of Applied Business and Economic Research, 203-213. Times, T. R. (2019, october 15). www.posist.com. Retrieved from www.posist.com (smergers, 2019) (tax, 2019) 